\title{
Hodgkin Lymphoma in Temporal Association with Growth Hormone Replacement
}

\author{
RENEE J. FREEDMAN, VERA MALKOVSKA*, DEREK LEROITH** AND MiCHAEL T. COLLINS*** \\ Developmental Endocrinology Branch, National Institute of Child Health and Human Development, 10 Center Drive, Building 10, \\ Bethesda, MD, 20892, USA \\ *Washington Cancer Institute, Washington Hospital Center, 110 Irving St. N.W, Washington, D. C. 20010, USA \\ **Clinical Endocrinology Branch, National Institute of Diabetes, Digestive and Kidney Diseases, 10 Center Drive, Building 10, \\ Bethesda, MD, 20892, USA \\ ***Craniofacial and Skeletal Diseases Branch, National Institute of Dental and Craniofacial Research, National Institutes of Health, \\ Department of Health and Human Services, 10 Center Drive, Building 10, Bethesda, MD, 20892, USA
}

\begin{abstract}
The association between growth hormone (GH) replacement and malignancy has long been debated. We report a case of Hodgkin lymphoma that developed in temporal association with the initiation of GH replacement in a 57-yearold woman with panhypopituitarism secondary to a non-secretory pituitary macroadenoma. Treatment of her pituitary tumor included transphenoidal surgery, external beam radiation, Bromocriptine and Cabergaline therapy. In addition to replacement steroid, thyroid and sex hormones, she insisted on GH replacement. Approximately 2 years after GH initiation, the diagnosis of Hodgkin lymphoma was made. Although the exact contribution of GH to the development of Hodgkin disease in our patient is unclear and a causal effect cannot be concluded, the temporal association is suggestive, and warrants reporting as part of ongoing surveillance for potential complications of GH replacement.
\end{abstract}

Key words: Hematology, Malignancy, Hormones, Panhypopituitary

(Endocrine Journal 52: 571-575, 2005)

THE association between growth hormone (GH) replacement and malignancy has long been debated. The 2001 consensus statement from the GH Research Society concluded that GH is safe for the currently approved indications [1]. It does recognize, however, that some aspects of GH replacement therapy require ongoing surveillance to determine long-term safety.

Despite in vitro and animal data demonstrating the mitogenic and proliferative properties of Human GH (HGH) [2-6], the occurrence of malignancies in patients on GH replacement is infrequently reported. Hematologic malignancies are even less frequently noted. Occurrence of leukemia in childhood onset GHD is also controversial. There are a few studies

Received: May 10, 2004

Accepted: June 27, 2005

Correspondence to: Renee J FREEDMAN, M.D., $1500 \mathrm{NW} 10^{\text {th }}$

Ave, Suite 205, Boca Raton, Florida 33484, USA describing an increase in the development of leukemia in children receiving pituitary GH replacement [7-10]. The cases of leukemia appear to occur predominantly in patients with prior craniopharyngioma or in children with other risk factors for leukemia [11]. A case of primary cerebral lymphoma has also been reported in a 22 year old patient, diagnosed 9 years after resection of a craniopharygioma and after 3 years of GH therapy [12]. In adults, there is one case report of Hodgkin disease developing in a cyclist using GH to enhance his athletic performance [13]. Furthermore, in Monson's report on the incidence of de novo neoplasia in the initial 3233 patients from the KIMS database (the Pharmacia \& Upjohn International Metabolic Database of adult patients with growth hormone deficiency (GHD) who are receiving recombinant human GH replacement therapy), the incidence of chronic lymphocytic leukemia (CLL) and lymphoma were both higher than multinational normative data [14]. A recent cohort 
study in 1848 patients in the UK found that those who were treated during childhood and early adulthood with human pituitary growth hormone between 1959 and 1985 had an increased mortality from cancer overall. They had increased risks of mortality from colorectal cancer and Hodgkin disease although the data were based on small numbers, only two cases for each disease. The standardised mortality ratio for colorectal cancer was $10.8,95 \%$ CI $1.3-38.8$ and for Hodgkin disease was $11.4,95 \%$ CI 1.4-41.3. Incidence of colorectal cancer was also raised $(7.9,1.0-28.7)$ [15].

Acromegaly, a state of excessive GH or IGF-1, has been associated with solitary benign and malignant tumors such as colon cancer [16-19], There are case reports of non-Hodgkin lymphoma and leukemia in patients with acromegaly [20]. GH levels, both basal and hypoglycaemia induced, were found to be higher in patients with hematologic malignancies including 33 subjects with Hodgkin lymphoma [21]. The levels of $\mathrm{GH}$ were higher in Hodgkin disease during relapse than while in remission.

In an effort to contribute to the ongoing surveillance, we report a case of Hodgkin lymphoma that developed in temporal association with the initiation of $\mathrm{GH}$ replacement in a 57-year-old woman with panhypopituitarism secondary to a non-secretory pituitary macroadenoma.

\section{Case History}

The patient is a 57-year-old woman who presented in 1976 at the age of 32 with amenorrhoea and galactorrhea. After investigation, she was found to have a mild elevation in prolactin and a pituitary tumor with suprasellar extension. She underwent transsphenoidal surgical (TSS) resection of the tumor and pathology revealed a chromophil macroadenoma. Post operatively her menses resumed and her prolactin, thyroid function tests (TFT's), cortisol and GH were normal.

In 1983, she was referred to the NIH for evaluation of asymptomatic gradual enlargement of the pituitary macroadenoma. Medical treatment was initiated with bromocriptine. This was ineffective and she required focused external beam radiation ( $50.40 \mathrm{~Gy}$ ) for cavernous sinus extension of the tumor in 1986. In 1993, due to asymptomatic optic nerve compression and growth around the pituitary stalk, she underwent a second partial TSS. The pathology revealed a null cell adenoma
$(2.3 \times 1.3 \times 0.4 \mathrm{~cm})$, which stained for alpha subunit, but not for ACTH, GH, Prolactin, FSH, LH or TSH. Post operatively, she had a sub-optimal response to ACTH stimulation and glucocorticoid replacement therapy (Hydrocortisone $20 \mathrm{mg}$ qam and $5 \mathrm{mg}$ qpm) was initiated. In August 2000, Cabergoline was added due to the development of right lateral diplopia and ptosis despite normal visual field testing and no further optic chiasm compression on MRI.

In July 1998, the patient requested GH replacement in an effort to alleviate symptoms of decreased energy and strength, memory loss and poor attention span. She was already on adequate thyroid hormone and intermittent sex steroid replacement. Serum IGF-1 and GH were $17 \mathrm{ng} / \mathrm{ml}$ (normal 29-90) and $<0.1 \mathrm{ng} / \mathrm{ml}$ respectively. Her percent body fat by DEXA was $34.6 \%$ and her lean mass was $43.25 \mathrm{~kg}$. She was started on GH replacement (Humatrope, Lilly, Indiana) in March 1999 at a dose of $1.5 \mathrm{U} / \mathrm{d}$ and serum IGF-1 level rose to $121 \mathrm{ng} / \mathrm{mL}$. After decreasing the $\mathrm{GH}$ dose to $1.0 \mathrm{U} / \mathrm{d}$ her IGF-1 level was $27 \mathrm{ng} / \mathrm{mL}$. She finally maintained a stable IGF-1 level of $66 \mathrm{ng} / \mathrm{ml}$ alternating between 1.0 and $1.5 \mathrm{U} / \mathrm{d}$ of GH. In June 2001, her percent body fat decreased to $27.9 \%$ and her lean mass increased to $45.54 \mathrm{~kg}$. Her symptoms of fatigue, low energy and poor memory improved dramatically.

In May 2000, physical examination revealed a $1.5 \times 1.5 \mathrm{~cm}$ left mid-cervical and a $3.0 \times 2.0 \mathrm{~cm}$ right supraclavicular lymph node. Surgical consultation and CT were obtained and the lymphadenopathy was felt to be possibly reactive secondary to a recent dental and maxillary infection. Her lymphadenopathy waxed and waned in size over more then 6 months. The patient was reluctant to have a lymph node biopsy, but one was eventually performed in May 2001. It revealed classical Hodgkin lymphoma histological subtype was mixed cellularity. Immunohistochemical studies demonstrated that the classical Reed-Sternberg cells were positive for CD15 and CD30 antigens. CT scans revealed pathological adenopathy both above and below the diaphragm. The largest nodes measured up to $3.0 \mathrm{~cm}$. Bone marrow biopsy was negative. The disease was staged as IIIB. Her GH was discontinued and she was treated with ABVD (Adriamycin, Bleomycin, Vinblastine and Daunorubicin) chemotherapy for three cycles, but then developed Bleomycin toxicity, specifically, biopsy proven granulomatous myositis. She received a further three cycles of chemotherapy with prednisone replacing the Bleomycin. Imaging studies 
revealed disease progression and she went on to induction chemotherapy and an autologous stem cell transplant.

The patient's past medical history was significant for a benign fallopian tube tumor and basal cell carcinoma. Both were removed surgically without recurrence. She was treated for verruca vulgaris of her right foot with cryotherapy, laser and topical bleomycin. There was no history of diabetes, or known coronary artery disease. Medications prior to the diagnosis of Hodgkin lymphoma included: L-thyroxine $125 \mathrm{ug} / \mathrm{d}$, Hydrocortisone, $15 \mathrm{mg}$ qam and $2.5 \mathrm{mg}$ qpm, Cabergoline $4000 \mathrm{mcg}$ weekly, Estrogen patch 50 ug twice per week, Medroxyprogesterone acetate $5 \mathrm{mg} \times 12$ days of the month, Calcium $500 \mathrm{mg} / \mathrm{d}$, Vit E $400 \mathrm{IU} / \mathrm{d}$, Budesonide 1 spray BID, Humatrope alternating between 1 and $1.5 \mathrm{U} / \mathrm{d}$ sc, Multivitamin daily, St Johns Wort 1 tablet/day, and DHEA $25 \mathrm{mg}$ daily. The patient's family history was not significant for pituitary tumors, however her brother was treated for nonHodgkin lymphoma at a young age. She had no history of smoking, alcohol abuse or IV drug use. She worked as a psychotherapist, was married and had two children.

Physical examination prior to the diagnosis of Hodgkin disease revealed a blood pressure of 166/100, heart rate of 90 beats per minute and a weight of $74.2 \mathrm{~kg}$. Head and neck examination revealed a right sided partial ptosis with normal extra ocular movements and visual fields. The remainder of her examination, including a neurological examination was normal. Laboratory tests in February 2001 included normal electrolytes, renal function and CBC. Her total and unconjugated bilirubin were elevated at $1.7 \mathrm{mg} / \mathrm{dL}$ $(\mathrm{N}=0.1-1)$ and $1.4 \mathrm{mg} / \mathrm{dL}(\mathrm{N}=0-0.2)$ respectively. Her LDH was elevated at 396 units/L $(\mathrm{N}=113-226)$. Her IGF-1 was $45 \mathrm{ng} / \mathrm{mL}(\mathrm{N}=71-290)$.

\section{Discussion}

While this case presents a clear temporal association between the initiation of GH replacement therapy and the development of Hodgkin lymphoma, a causal effect cannot be concluded. Nonetheless, given the need for the close ongoing surveillance in patients receiving this therapy, it warrants reporting.

The exact contribution of GH to the development of HD in our patient is unclear. Her family history of a first degree relative with non-Hodgkin lymphoma and her past medical history of prior neoplasms including a benign fallopian tube tumor, a basal cell cancer at a young age, and an aggressive pituitary macroadenoma suggest a genetic predisposition for malignancy.

GH replacement in our patient had several important benefits. It improved dramatically her sense of well being, energy level and quality of life. It also increased her lean body mass and decreased her fat mass. These effects have been reported by others in large randomized control trials [22-25].

As elevated IGF-1 has been associated with certain

Table 1. Summary of events

\begin{tabular}{|c|c|c|c|c|}
\hline $\begin{array}{c}\text { Age }(\mathrm{yrs}) \\
\text { (Date }(+/-\mathrm{mo} / \mathrm{yr})\end{array}$ & Pituitary Tumor Status & Pituitary Tumor Treatment & $\begin{array}{l}\text { Pituitary Hormone } \\
\text { Replacement }\end{array}$ & Other \\
\hline $32(1976)$ & $\begin{array}{l}\text { Pituitary macroadenoma } \\
\text { discovered }\end{array}$ & TSS & None & \\
\hline $39(1983)$ & Tumor enlargement & Bromocriptine & None & \\
\hline $42(1986)$ & Cavernous sinus invasion & $\begin{array}{l}\text { External Beam Radiation } \\
\quad(50.40 \mathrm{~Gy})\end{array}$ & None & \\
\hline $49(1993)$ & $\begin{array}{l}\text { Optic nerve and stalk } \\
\text { compression }\end{array}$ & Partial TSS & $\begin{array}{l}\text { Hydrocortisone, thyroid and } \\
\text { sex hormone }\end{array}$ & \\
\hline $55(3 / 1999)$ & & & GH replacement & \\
\hline $56(5 / 2000)$ & & & & $\begin{array}{l}\text { Lymphadenopathy } \\
\text { discovered }\end{array}$ \\
\hline $57(2000)$ & $\begin{array}{l}\text { Ptosis and right lateral } \\
\text { diplopia }\end{array}$ & Cabergoline & & \\
\hline $58(5 / 2001)$ & & & & $\begin{array}{l}\text { Lymph node biopsy } \\
\text { (positive for Hodgkin } \\
\text { lymphoma) }\end{array}$ \\
\hline
\end{tabular}


malignancies it is important to monitor IGF-1 levels when starting someone on GH replacement and adjust the dose of GH aiming for IGF-1 levels within the ageand gender-specific normal range. In this patient the serum IGF-1 level was only transiently above the age-specific normal range but otherwise remained in the normal or low range on all measurements.

The limited and inconclusive evidence in the literature fail to demonstrate a clear causal relation between $\mathrm{GH}$ and de novo malignancy [1]. The relationship be- tween GH and malignancy could be clarified through better understanding of the molecular mechanisms of malignant transformation or perhaps by future long term randomized controlled studies. Although GH therapy may have important benefits, this case demonstrates that it must be used cautiously, especially in high risk groups, which remain to be defined. It is also essential that patients are well informed of the possible risks of GH.

\section{References}

1. (2001) Critical evaluation of the safety of recombinant human growth hormone administration: statement from the Growth Hormone Research Society. J Clin Endocrinol Metab 86: 1868-1870.

2. Zadik Z, Estrov Z, Karov Y, Hahn T, Barak Y (1993) The effect of growth hormone and IGF-I on clonogenic growth of hematopoietic cells in leukemic patients during active disease and during remission - a preliminary report. J Pediatr Endocrinol 6: 79-83.

3. Estrov Z, Meir R, Barak Y, Zaizov R, Zadik Z (1991) Human growth hormone and insulin-like growth factor-1 enhance the proliferation of human leukemic blasts. J Clin Oncol 9: 394-399.

4. Lee PD, Rosenfeld RG, Hintz RL, Smith SD (1986) Characterization of insulin, insulin-like growth factors I and II, and growth hormone receptors on human leukemic lymphoblasts. J Clin Endocrinol Metab 62: 28-35.

5. Weigent DA, Blalock JE (1989) Expression of growth hormone by lymphocytes. Int Rev Immunol 4: 193211.

6. Murphy WJ, Durum SK, Anver M, Frazier M, Longo DL (1992) Recombinant human growth hormone promotes human lymphocyte engraftment in immunodeficient mice and results in an increased incidence of human Epstein Barr virus-induced B-cell lymphoma. Brain Behav Immun 6: 355-364.

7. Endo M, Kaneko Y, Shikano T, Minami H, Chino J (1988) Possible association of human growth hormone treatment with an occurrence of acute myeloblastic leukemia with an inversion of chromosome 3 in a child of pituitary dwarfism. Med Pediatr Oncol 16: 45-47.

8. Fradkin JE, Mills JL, Schonberger LB, Wysowski DK, Thomson R, Durako SJ, Robison LL (1993) Risk of leukemia after treatment with pituitary growth hormone. Jama 270: 2829-2832.

9. Magnavita N, Sica S, Di Mario A, Leone G (1996) Concurrent epiphyseal fracture and leukemia in a patient treated with growth hormone. Am J Hematol
51: 95-96.

10. Watanabe STY, Komiyama A, Fujimoto J (1988) Leukaemia in patients treated with growth hormone. Lancet 1: 1159-1160.

11. Nishi Y, Tanaka T, Takano K, Fujieda K, Igarashi Y, Hanew K, Hirano T, Yokoya S, Tachibana K, Saito T, Watanabe S (1999) Recent status in the occurrence of leukemia in growth hormone-treated patients in Japan. GH Treatment Study Committee of the Foundation for Growth Science, Japan. J Clin Endocrinol Metab 84: 1961-1965.

12. Forbes GM, Cohen AK (1992) Primary cerebral lymphoma: an association with craniopharyngioma or cadaveric growth hormone therapy? Med J Aust 157: 27-28.

13. Magnavita N, Teofili L, Leone G (1996) Hodgkin's lymphoma in a cyclist treated with growth hormone. Am J Hematol 52: 65-66.

14. Monson JP (2000) Growth hormone (GH) replacement therapy: cancer in adults treated with GH. Growth Horm IGF Res 10 (Suppl A): S50-S51.

15. Swerdlow AJ, Higgins CD, Adlard P, Preece MA (2002) Risk of cancer in patients treated with human pituitary growth hormone in the UK, 1959-85: a cohort study. Lancet 360: 273-277.

16. Jenkins PJ (2000) Acromegaly and colon cancer. Growth Horm IGF Res 10 (Suppl A): S35-S36.

17. Jenkins PJ, Besser GM, Fairclough PD (1999) Colorectal neoplasia in acromegaly. Gut 44: 585-587.

18. Jenkins PJ, Besser M (2001) Clinical perspective: acromegaly and cancer: a problem. J Clin Endocrinol Metab 86: 2935-2941.

19. Jenkins PJ, Fairclough PD, Richards T, Lowe DG, Monson J, Grossman A, Wass JA, Besser M (1997) Acromegaly, colonic polyps and carcinoma. Clin Endocrinol (Oxf) 47: 17-22.

20. Intebi AD, Deutsch SI, Benedetti D, Diez RA (1995) Acromegaly and large cell lymphoma. Acta Haematol 94: 214-215. 
21. Pavelic K, Pekic B, Gabrilovac J, Bratic-Mikes V, Boranic M (1981) Hormonal changes in patients with haematological malignancies. Biomedicine 35: 181-184.

22. Wallymahmed ME, Foy P, Shaw D, Hutcheon R, Edwards RH, MacFarlane IA (1997) Quality of life, body composition and muscle strength in adult growth hormone deficiency: the influence of growth hormone replacement therapy for up to 3 years. Clin Endocrinol (Oxf) 47: 439-446.

23. Verhelst J, Abs R, Vandeweghe M, Mockel J, Legros JJ, Copinschi G, Mahler C, Velkeniers B, Vanhaelst L, Van Aelst A, De Rijdt D, Stevenaert A, Beckers A (1997) Two years of replacement therapy in adults with growth hormone deficiency. Clin Endocrinol (Oxf) 47: 485-494.

24. Verhelst J, Abs R (2002) Long-term growth hormone replacement therapy in hypopituitary adults. Drugs 62: 2399-2412.

25. Cuneo RC, Judd S, Wallace JD, Perry-Keene D, Burger H, Lim-Tio S, Strauss B, Stockigt J, Topliss D, Alford F, Hew L, Bode H, Conway A, Handelsman D, Dunn S, Boyages S, Cheung NW, Hurley D (1998) The Australian Multicenter Trial of Growth Hormone (GH) Treatment in GH-Deficient Adults. J Clin Endocrinol Metab 83: 107-116. 